\title{
Neuroticism Sebagai Moderator Dalam Hubungan Antara Komitmen Dan Motif Berkorban Dalam Hubungan Berpacaran
}

\section{The Moderating Role Of Neuroticism On The Relationship Between Commitment And Motives Of Sacrifice Among Dating Relationship}

\author{
Sere Eunice Kantate ${ }^{1}$, Dian Wisnuwardhani ${ }^{1}$ \\ ${ }^{1}$ Fakultas Psikologi, Universitas Indonesia \\ dianwisnu15@gmail.com
}

\begin{abstract}
Abstrak
Penelitian korelasional ini bertujuan untuk mengetahui apakah neuroticism dapat memoderasi hubungan antara komitmen dan motif berkorban. Alat ukur yang digunakan dalam penelitian ini adalah Motives of Sacrifice (Impett, Gable, \& Peplau, 2005) untuk mengukur motif berkorban, The Investment Model (Rusbult, Martz, \& Agnew, 1998) untuk mengukur komitmen, dan Big Five Inventory (BFI) (Ramdhani, 2012) untuk mengukur neuroticism. Data yang didapat ialah 954 individu, dengan $80,9 \%$ responden perempuan, yang sedang menjalani hubungan berpacaran, ditemukan bahwa terdapat hubungan yang signifikan antara motif berkorban baik approach motives $(r=0,26, p=0,00 ; p<0,01$, two tails) maupun avoidance motives ( $r=0,09, p=0,00 ; p<0,01$, two tails) dengan komitmen. Individu yang memiliki komitmen tinggi cenderung berkorban demi pasangannya, baik dengan approach motives maupun avoidance motives. Akan tetapi, ditemukan bahwa neuroticism tidak memoderasi hubungan antara motif berkorban, baik approach motives $(t=0,90, p=0,27 ; p>0,05)$ maupun avoidance motives $(t=0,51, p=0,61 ; p>0,05)$ dengan komitmen.
\end{abstract}

Kata kunci: Komitmen; Hubungan berpacaran; Motif berkorban; Neuroticism; Dewasa muda

\begin{abstract}
This correlational study aims to find out whether neuroticism moderates the relationship between motives of sacrifice and commitment. Instruments used in this study are Motives of Sacrifice (Impett, Gable, \& Peplau, 2005) to measure motives of sacrifice, The Investment Model (Rusbult, Martz, \& Agnew, 1998) to measure commitment, and Big Five Inventory (Ramdhani, 2012) to measure neuroticism. Data gathered from 954 young adults, 80,9\% female, who are in dating relationships shows a significant relationship between motives of sacrifice, including approach motives $(\mathrm{r}=0,26, \mathrm{p}=0,00 ; \mathrm{p}<$ 0,01 , two tails) and avoidance motives motives ( $\mathrm{r}=0,09, \mathrm{p}=0,00 ; \mathrm{p}<0,01$, two tails), and commitment. Individuals with high commitment tend to sacrifice for their partner, either with approach motives or avoidance motives. However, neuroticism is not found to moderate the relationship between motives of sacrifice, for both approach motives $(\mathrm{t}=0,90, \mathrm{p}=0,27 ; \mathrm{p}>0,05)$ and avoidance motives $(\mathrm{t}=0,51, \mathrm{p}=$ $0,61 ; \mathrm{p}>0,05)$, and commitment.
\end{abstract}

Keywords: Commitment; Dating relationship; Motives of sacrifice; Neuroticism; Young adulthood; 


\section{Pendahuluan}

Dewasa muda yang berusia antara 20-39 tahun, menurut Erikson Psychosocial Approach, sedang menjalani tugas perkembangan intimacy vs isolation (Papalia \& Martorell, 2014; Miller, 2014). Salah satu karakteristik dari individu yang telah mencapai tahap intimacy ialah ketika individu memiliki komitmen yang mendalam terhadap orang lain.

Untuk mencapai tahap intimacy, salah satu hal yang dapat dilakukan ialah dengan memiliki hubungan berpacaran. Bennet (dalam Wisnuwardhani \& Mashoedi, 2012) menjelaskan hubungan berpacaran sebagai hubungan yang dijalani oleh pria dan wanita sebelum menjalani pernikahan yang memiliki fungsi utama untuk mengembangkan kemampuan hubungan interpersonal pada diri individu terebut.

Di Indonesia, pacaran seringkali dikatakan sebagai hubungan antara individu untuk dapat lebih mengenal pasangan masing masing dan dapat membuat hubungan bertahan lebih lama. Pandangan masyarakat tentang pacaran ini beragam, selain mendukung, ada yang menentang karena dikhawatirkan sampai pada perilaku perzinahan. Maka, bagi yang berpacaran perlu memperhatikan norma agama dan masyarakat tersebut dengan memastikan terhindar dari perilaku perzinahan.

Penelitian dari Yulika \& Setiawan (2017) yang mewawancarai para santri memaparkan bahwa tujuan pacaran adalah untuk membangun keharmonisan hubungan antara pasangan. Hal ini menunjukkan tujuan berpacaran tersebut adalah kesempatan mengenal kelebihan dan kekurangan dari pasangan sehingga ketika menikah mereka telah memahami terlebih dahulu sifat satu sama lain sehingga diharapkan dapat menurunkan konflik pasangan suami istri dan kecenderungan perceraian.

Dalam sebuah hubungan berpacaran, terdapat dua individu yang memiliki perbedaan antar satu dengan lainnya, dimana setiap manusia diciptakan unik dan berbeda dari yang lain. Perbedaan yang terjadi pada pasangan tidak jarang menimbulkan masalah dalam hubungan tersebut yang tidak dapat dihindari (Mattingly, 2008). Salah satu cara yang dapat dilakukan individu untuk menyelesaikan masalah akibat dari perbedaan yang terjadi dalam hubungannya ialah dengan meninggalkan ketertarikannya pada suatu hal untuk kesejahteraan pasangan maupun hubungan yang dimiliki, yang dapat disebut sebagai sacrifice, dan lebih lanjut akan disebut sebagai berkorban (Van Lange, Rusbult, Drigotas, Arriaga, Witcher, \& Cox, 1997). Sejalan dengan itu, Mattingly dan Clark (2010) juga mengatakan bahwa berkorban diperlukan dalam sebuah hubungan berpacaran, yaitu untuk menyelesaikan konflik yang terjadi.

Berkorban adalah kecenderungan individu untuk mengesampingkan kemauan diri sendiri untuk meningkatkan kesejahteraan pasangannya (Van Lange, dkk., 1997). Berkorban dapat dibedakan berdasarkan jenis, alasan, serta derajatnya. Berdasarkan derajatnya, terdapat perbedaan antara berkorban dalam kehidupan sehari-hari dengan berkorban yang dianggap penting bagi jangka panjang (Impett, Gable, \& Peplau, 2005). Survei di Amerika Serikat terhadap 364 individu pada rentang usia sekitar 20 hingga 39 tahun menemukan bahwa terdapat 86\% individu rela berpindah ke kota lain jika pasangannya mendapatkan pekerjaan yang lebih baik, bahkan $46 \%$ responden rela berpindah ke negara lain (Prakoswa, 2018).

Ketika seorang individu berkorban, ia akan meninggalkan ketertarikannya demi pasangan sehingga akan terdapat dampak positif maupun negatif yang akan diterima. Dampak yang diterima individu dalam berkorban, baik yang merupakan keuntungan maupun kerugian, dipengaruhi oleh alasan atau motif yang mendasari individu dalam berkorban (Impett \& Gordon, 2008). Menurut Impett, Gable, dan Peplau (2005), dalam berkorban, alasan atau motif yang mendasari individu ketika berkorban disebut sebagai motif berkorban. Terdapat dua motif dasar dalam berkorban yaitu approach motives dan avoidance motives (Impett, Gable, \& Peplau, 2005).

Approach motives dijelaskan sebagai dorongan atau alasan individu berkorban ialah untuk mendapatkan hasil yang positif, seperti menguntungkan pasangannya maupun memperkuat hubungan yang dimiliki. Salah satu contohnya ialah ketika individu memilih untuk menonton film yang disukai pasangannya dengan tujuan agar melihat pasangannya senang dan keduanya bisa semakin dekat. Selanjutnya, avoidance motives dijelaskan sebagai dorongan atau alasan individu berkorban untuk menghindari hasil yang negative, seperti pertengkaran ataupun pengalaman yang tidak diinginkan dalam sebuah hubungan. Salah satu contohnya ialah ketika individu memilih untuk menonton film yang 
disukai pasangannya dengan tujuan agar ia terhindar dari masalah atau kemungkinan munculnya pertengkaran dalam hubungan.

Terdapat beberapa hal yang telah terbukti mampu memengaruhi motif individu dalam berkorban. Pertama yaitu komitmen. Sebagai salah satu motif utama dalam keberlangsungan sebuah hubungan. Van Lange, dkk., (1997), menyatakan bahwa semakin berkomitmen, individu cenderung semakin lebih mementingkan kesejahteraan pasangan maupun hubungan dari pada dirinya sendiri sehingga individu cenderung mengesampingkan ketertarikannya sendiri. Selain itu, usia dan jenis kelamin individu. Nikitin dan Freund (2008) menyatakan bahwa dalam masa transisi memasuki fase dewasa muda, individu cenderung akan menggunakan avoidance motives dalam aspek kehidupan sosialnya, termasuk dalam hubungan berpacaran yang dijalani. Jenis kelamin juga menjadi faktor yang mampu memengaruhi motif berkorban. Whitton, Stanley, \& Markman (2002) mengemukakan bahwa perempuan lebih terasosisasi untuk berkorban. Bahkan, perempuan cenderung memandang perilaku berkorban sebagai sebuah tuntutan dan sebuah perilaku yang sudah sepatutnya dilakukan oleh kaum perempuan (Cooper, Totenhagen, Curran, Randall, \& Smith, 2017)

Penelitian menemukan bahwa komitmen dapat memengaruhi individu dalam berkorban (Kurdek, 1997; Van Lange, dkk., 1997). Komitmen oleh Rusbult (1983) dijelaskan sebagai kecenderungan individu untuk mempertahankan sebuah hubungan dan juga merasa terikat secara psikologis dalam hubungan tersebut. Oleh karena itu, dapat diasumsikan bahwa individu yang memiliki tingkat komitmen tinggi cenderung mampu mempertahankan hubungan sehingga hubungan yang dijalaninya akan berlangsung secara lama dan kemungkinan kecil akan kandas dalam waktu singkat. Selain itu, komitmen dianggap sebagai konstruk psikologis yang secara langsung memengaruhi perilaku sehari-hari individu dalam hubungannya dengan pasangan (Rusbult, Agnew, \& Arriaga, 2011).

Terdapat 3 (tiga) faktor utama yang memiliki pengaruh kuat akan tingkat komitmen individu yaitu tingkat kepuasan, kualitas alternatif, dan tingkat investasi (Rusbult, 1983). Semakin tinggi tingkat kepuasan individu dalam sebuah hubungan, maka semakin tinggi pula tingkat komitmen individu karena pasangannya mampu memenuhi kebutuhan dirinya (Rusbult, 1983). Kualitas alternatif merupakan alternative selain pasangan yang mampu memenuhi kebutuhan individu, seperti keluarga, teman, bahkan diri sendiri. Semakin tinggi kemungkinan bahwa kebutuhan individu dapat dipenuhi oleh alternatif lain, maka komitmen yang dimiliki individu juga akan semakin menurun (Rusbult, 1983). Tingkat investasi dalam hubungan merupakan berbagai hal yang telah diberikan oleh individu, yang berasal dari berbagai macam sumber daya, mulai dari waktu, tenaga, bahkan mungkin uang, demi keberlangsungan hubungan yang dijalaninya. Semakin besar investasi yang telah diberikan individu terhadap pasangannya, semakin tinggi pula tingkat komitmen individu karena individu tersebut merasa ia akan dirugikan karena kehilangan banyak hal jika ia tidak mampu mempertahankan hubungan tersebut.

Penelitian sebelumnya telah menemukan dampak komitmen terhadap kehidupan individu di berbagai aspek. Salah satu hal yang sangat dipengaruhi oleh komitmen ialah persistensi hubungan. Menurut Rusbult, dkk. (1998), individu yang memiliki komitmen tinggi cenderung lebih mampu mempertahankan sebuah hubungan romantis. Hal tersebut terjadi karena individu memiliki orientasi jangka panjang mengenai hubungan tersebut sehingga dalam menjalaninya, individu cenderung mengasosiasikan pasangannya pada masa depannya sehingga hubungan yang dimilikinya cenderung lebih bertahan lama dibandingkan dengan individu yang memiliki komitmen rendah (Rusbult, dkk., 1998). Selain itu, individu dengan komitmen tinggi juga cenderung lebih memiliki intensi untuk bertahan dalam hubungan (Arriaga \& Agnew, 2001). Selain dikarenakan orientasi jangka panjang, individu juga memiliki keterikatan psikologis yang lebih tinggi sehingga mengakhiri sebuah hubungan dianggap dapat memberikan dampak yang buruk bagi individu.

Salah satu karakteristik individu dengan komitmen tinggi ialah memiliki kemauan untuk mengorbankan kemauan dirinya sendiri demi keberlangsungan hubungan yang sedang dijalaninya. Individu dengan komitmen tinggi percaya bahwa apapun yang baik bagi pasangannya juga baik untuk dirinya sendiri, sehingga ia akan rela untuk berkorban demi kebahagiaan pasangannya (Van Lange, dkk., 1997). Dengan demikian, ia dengan sukarela berkorban pada berbagai macam situasi yang ada demi kebahagiaan pasangan maupun hubungan keduanya. Dari sini, dapat dilihat bahwa individu yang memiliki komitmen tinggi cenderung akan menggunakan approach motives ketika berkorban. 
Akan tetapi, terdapat beberapa penelitian yang memberikan hasil yang berbeda. Penelitian Mattingly (2008) menemukan bahwa komitmen tidak memiliki hubungan yang signifikan dengan motif berkorban pada individu. Namun demikian, penelitian Mattingly (2008) merupakan penelitian eksperimen yang menyatakan bahwa lebih baik menggunakan pengukuran self-report untuk mengukur motif berkorban, sehingga memperkuat asumsi bahwa untuk meneliti motif berkorban, lebih baik menggunakan penelitian korelasional.

Selain itu, terdapat indikasi bahwa terdapat faktor lain yang memengaruhi hubungan antara komitmen dan motif berkorban. Penelitian menemukan bahwa faktor lain yang dapat berperan dalam hubungan adalah kepribadian (Figueredo, Sefcek, \& Jones, 2006). Kepribadian secara umum dijelaskan sebagai sebuah pola yang cenderung menetap dari trait (sifat) maupun karakteristik yang unik yang menghasilkan perilaku individu yang konsisten dan individualitas (Feist \& Feist, 2009). Dalam teori Big Five, terdapat lima trait kepribadian yaitu extraversion, agreeableness, openness to experience, conscientiousness, dan neuroticism. Menurut Kurdek (1997), neuroticism merupakan satu-satunya trait kepribadian yang memiliki hubungan unik dengan hasil akhir dari sebuah hubungan romantis karena trait neuroticism cenderung memiliki dampak yang negatif pada sebuah hubungan.

Neuroticism dijelaskan sebagai trait mengenai stabilitas emosi, yang mengacu pada kecenderungan keadaan emosi individu yang negatif sehingga secara konsisten individu merasa mudah cemas dan juga marah (Feist \& Feist, 2008). Pengalaman dengan emosi negatif tersebut cenderung konsisten, tetapi sebenarnya tidak menyenangkan (Tamir, 2005). Individu dengan neuroticism tinggi cenderung hanya berfokus pada hal yang negatif dalam hidup dibandingkan dengan melihat hal positif yang ada (Feist \& Feist, 2008). Individu yang memiliki neuroticism tinggi cenderung gelisah, emosional, mengasihani diri sendiri, mudah marah, dan rentan terhadap stres, berbanding dengan individu yang memiliki neuroticism rendah yang cenderung tenang, puas dengan diri sendiri, dan tidak mudah emosional (Feist \& Feist, 2008). Individu dengan tingkat neuroticism tinggi juga cenderung mengalami kesulitan dalam mempertahankan hubungan dengan pasangan karena individu cenderung mengatur standar yang tidak realistis (Kurdek, 1997).

Ketika memiliki hubungan dengan orang lain, individu dengan neuroticism tinggi cenderung memiliki kepuasan hubungan yang rendah dan lebih banyak memiliki konflik (John, Naumann, \& Soto, 2008). Karakteristik lain dari individu dengan tingkat neuroticism tinggi ialah memiliki toleransi yang rendah terhadap kekecewaan dan konflik, sehingga memiliki kecenderung akan menghindari semua hal yang dianggap akan menyebabkan masalah, salah satunya ialah perbedaan dalam sebuah hubungan (Ramdhani, 2012).

Penelitian Tamir (2005) mendapatkan hasil bahwa individu dengan neuroticism tinggi memiliki beberapa karakteristik seperti kecenderungan untuk menghindari hal-hal yang dapat menimbulkan masalah bagi dirinya sendiri, ataupun hal-hal yang tidak diinginkan pada semua aspek, termasuk dalam sebuah hubungan. Oleh karena itu, ketika individu dengan neuroticism yang tinggi berkorban, ia cenderung melakukannya untuk menghindarkan dirinya dari masalah atau hukuman yang mungkin akan didapatkan nanti. Dengan demikian, peneliti menyimpulkan terdapat indikasi bahwa individu dengan tingkat neuroticism yang tinggi cenderung berkorban dengan avoidance motives.

Dalam penelitiannya, Kurdek (1997), mengatakan bahwa individu yang memiliki neuroticism tinggi cenderung memiliki kesulitan untuk mempertahankan hubungannya. Di sisi lain, individu dengan komitmen tinggi cenderung gigih bertahan dalam sebuah hubungan (Rusbult, 1980). Dari sini dapat dilihat bahwa individu yang memiliki neuroticism tinggi cenderung memiliki komitmen yang rendah dalam hubungannya.

Berdasarkan uraian di atas, peneliti menduga adanya peran neuroticism sebagai moderator dalam hubungan antara komitmen dan motif berkorban. Hal ini disebabkan oleh adanya hubungan negatif antara komitmen dan neuroticism, yaitu individu dengan komitmen tinggi cenderung akan memiliki neuroticism yang rendah, begitupun sebaliknya. Selain itu, neuroticism juga diduga dapat memperlemah hubungan antara komitmen dan motif berkorban, terutama pada approach motives, karena individu dengan neuroticism cenderung menggunakan avoidance motives dalam berkorban, sedangkan, seperti yang telah dijelaskan sebelumnya, individu dengan komitmen tinggi cenderung akan menggunakan approach motives ketika berkorban. 
Mengingat masih sedikitnya penelitian mengenai motif berkorban, peneliti memutuskan untuk meneliti hubungan antara komitmen dan motif berkorban dengan neuroticism sebagai moderator. Hal ini penting diteliti karena berkorban dan komitmen merupakan hal yang penting bagi kelangsungan dan kualitas hubungan (Van Lange, et. al., 1997; Impett \& Gordon, 2008). Maka dari itu, tujuan penelitian ini adalah untuk mengetahui apakah terdapat hubungan antara komitmen dan motif berkorban dengan neuroticism sebagai moderator pada dewasa muda yang berpacaran.

\section{Metode Penelitian}

Penelitian ini merupakan penelitian non-eksperimental, yaitu penelitian korelasional, yang bertujuan untuk mendapatkan hubungan antar variabel dan menetapkan bahwa terdapat hubungan antara dua variabel/lebih untuk menguraikan hakikat dari hubungan antar variabel tersebut (Gravetter \& Forzano, 2012). Penelitian ini menggunakan desain cross-sectional study, yaitu penyebaran dan pengumpulan data yang dilakukan hanya dengan satu kali pengambilan (Gravetter \& Forzano, 2012).

Sampel dari penelitian ini akan diambil dari populasi dewasa muda yang berusia 20-39 tahun, sedang berpacaran, dan memiliki orientasi heteroseksual. Tipe pengambilan sampel yang digunakan untuk penelitian ini adalah tipe non-probability sampling, yaitu tipe pengambilan sampling ketika jumlah populasi tidak diketahui secara lengkap sehingga kemungkinan tiap individu untuk dipilih sebagai sampel tidak sama (Gravetter \& Frozano, 2009). Teknik yang digunakan dalam penelitian ini adalah teknik accidental sampling dengan memilih individu yang bersedia untuk mengikuti penelitian ini (Gravetter \& Forzano, 2009).

Terdapat tiga variabel dalam penelitian ini sehingga akan terdapat tiga alat ukur berbeda yang digunakan dalam penelitian. Alat ukur untuk mengukur variabel terikat motif berkorban, digunakan alat ukur Motives of Sacrifice oleh Impett, Gable, dan Peplau (2005) yang memiliki 10 item di dalamnya. Dalam 10 item tersebut, lima item untuk mengukur approach motives dan lima item untuk mengukur avoidance motives. Item yang ada merupakan pernyataan mengenai alasan individu berkorban bagi pasangannya. Untuk mengukur variabel bebas komitmen, digunakan alat ukur The Investment Model oleh Rusbult, Martz, dan Agnew (1998) mengenai level komitmen individu yang kemudian diterjemahkan oleh peneliti. Dari total 37 (tiga puluh tujuh) item, secara khusus terdapat 7 item untuk mengukur level komitmen. Terakhir, untuk mengukur variabel moderator neuroticism, digunakan alat ukur Big Five Inventory (BFI) oleh Ramdhani (2012). Dari total keseluruhan 28 item untuk mengukur lima traits utama kepribadian, terdapat 4 item yang mengukur traits neuroticism. Seluruh alat ukur yang digunakan akan dijawab menggunakan skala Likert dengan skala 1 (sangat tidak sesuai) hingga 6 (sangat sesuai) berdasarkan kesesuaian apakah pernyataan tersebut mendeskripsikan individu dalam kehidupannya. Seluruh alat ukur telah reliabel dan valid untuk mengukur masing-masing variabel.

Data yang didapat dalam penelitian ini selanjutnya akan diolah dan dianalisis menggunakan perangkat lunak PROCESS SPSS (Statistical Package of Social Science). Data yang didapat akan diawali dengan melakukan analisis statistik deskriptif, dilanjutkan dengan analisis korelasional, dan diakhiri dengan analisis moderasi untuk mendapatkan hasil utama penelitian. Analisis deskriptif dilakukan untuk mengetahui gambaran umum responden dari penelitian ini.

Tahap analisis korelasional dengan menggunakan Pearson's Product Moment Correlation untuk menguji hubungan korelasi antara motif berkorban, komitmen, dan neuroticism. Untuk mendapatkan hasil utama penelitian, dilakukan analisis moderasi menggunakan perangkat lunak tambahan Process by Andrew Hayes Macro untuk melihat apakah trait neuroticism berfungi sebagai moderator dalam hubungan antara komitmen dan motif berkorban.

\section{Hasil Penelitian}

Data awal yang didapat ialah sebesar 1.050 responden. Akan tetapi, setelah dilakukan pengecekan terhadap data mentah, terdapat beberapa responden yang tidak memenuhi kriteria penelitian. Contoh responden yang tidak memenuhi kriteria penelitian ialah responden yang hanya mengisi kurang dari $90 \%$ item alat ukur. Selanjutnya, peneliti juga mengeliminasi nilai outliers sehingga didapatkan hasil akhir sebanyak 954 respoden penelitian yang datanya dapat digunakan untuk analisis penelitian secara menyeluruh. 
Berdasarkan 954 data yang dapat diolah setelah melakukan pre-eliminary analysis, peneliti ingin mengetahui gambaran umum responden penelitian, untuk mengetahui persebaran dari responden pada penelitian ini. Usia responden akan dikelompokan sesuai dengan perbedaan pada rentang usia dewasa muda menurut James (dalam McCrae \& Costa, 2003), sedangkan lama pacaran akan dikelompokan berdasarkan empat tahapan dalam hubungan intim yang dijelaskan oleh Campbell (1980).

Didapatkan persebaran jenis kelamin responden tidak merata dengan mayoritas 772 responden ialah perempuan (80,9\%), diikuti 176 laki-laki (18,4\%), dan terdapat 6 responden yang tidak mengisi $(0,6 \%)$. Usia responden penelitian ini tersebar dari usia 20 hingga 39 tahun, tetapi paling banyak berusia antara 20 - 30 tahun $(98,5 \%)$. Terdapat 307 responden penelitian yang telah berpacaran selama kurang dari 1 tahun (32,3\%), 380 responden telah berpacaran selama 1 hingga 3 tahun (39,8\%), 154 responden telah berpacaran selama 3 hingga 5 tahun (16,1\%), 105 responden telah berpacaran selama di atas 5 tahun (11\%), dan 8 responden tidak mengisi lama pacaran $(0,8 \%)$.

Secara deskriptif, pada tabel 1 akan dijabarkan gambaran umum berupa mean atau rata-rata dan standar deviasi dari seluruh variabel utama penelitian:

Tabel 1. Gambaran Umum Variabel Penelitian

\begin{tabular}{cccc}
\hline Variabel & N & M & SD \\
\hline Approach Motives & 954 & 21,60 & 4,25 \\
Avoidance Motives & 954 & 20,23 & 5,25 \\
Komitmen & 954 & 36,33 & 4,94 \\
Neuroticism & 954 & 16,59 & 4,21 \\
\hline
\end{tabular}

Berdasarkan tabel 1, responden penelitian memiliki motif berkorban dengan kisaran skor 17,35 hingga 25,85 pada approach motives dan kisaran skor untuk avoidance motives ialah 14,98 dan 25,48. Dapat disimpulkan bahwa motif berkorban pada responden tergolong tinggi pada approach motives maupun avoidance motives. Pada variabel komitmen, responden penelitian memiliki skor berkisar antara 31,39 hingga 41,27. Dapat disimpulkan bahwa komitmen responden penelitian tergolong tinggi. Terakhir, pada variabel neuroticism, responden penelitian ini memiliki kisaran skor 12,38 hingga 20,8. Dapat disimpulkan bahwa responden penelitian ini memiliki tingkat neuroticism yang tergolong tinggi.

Setelah mendapatkan gambaran umum variabel penelitian, peneliti melakukan analisis korelasi antar variabel utama dan data demografis responden penelitian. Hasil akan dijabarkan pada Tabel 2 mengenai hasil korelasi antara approach motives dan data demografis serta pada Tabel 3 mengenai hasil korelasi antara avoidance motives dan data demografis:

Tabel 2. Analisis Korelasi Approach Motives dan Data Demografis

\begin{tabular}{lccc}
\hline \multicolumn{1}{c}{ Variabel } & $\boldsymbol{p}$ & Spearman & T-test \\
\hline Usia & 0,46 & 0,02 & - \\
Lama Berpacaran & 0,41 & 0,03 & - \\
Jenis Kelamin & 0,07 & - & $-1,84$ \\
\hline
\end{tabular}

${ }^{*}$ Korelasi signifikan pada $p<0,05$ (two-tailed $)$

Berdasarkan hasil analisis korelasi, approach motives tidak memiliki hubungan yang signifikan dengan usia individu $(r=0,02, p=0,46 ; p>0,05)$, lama berpacaran $(r=0,03, p=0,41 ; p>0,05)$, dan jenis kelamin $(r=-1,84, p=0,07 ; p>0,05)$. Maka dari itu, disimpulkan bahwa tidak ditemukan satupun variabel data demografis yang memiliki hubungan signifikan dengan approach motives. Selanjutnya, dilakukan pula analisis korelasi motif berkorban dengan data demografis dengan hasil: 
Tabel 3. Analisis Korelasi Motif Avoidance Motives dan Data Demografis

\begin{tabular}{|c|c|c|c|}
\hline Variabel & $p$ & Spearman & T-test \\
\hline Usia & 0,00 & $-0,13^{* *}$ & - \\
\hline Lama Berpacaran & 0,04 & $-0,00$ & - \\
\hline Jenis Kelamin & 0,90 & - & $-1,97^{*}$ \\
\hline
\end{tabular}

${ }^{*}$ Korelasi signifikan pada $p<0,05$ ( $t$ wo-tailed $)$

$* *$ Korelasi signifikan pada $p<0,01$ ( two-tailed) $^{*}$

Berdasarkan analisis korelasi yang dilakukan, didapatkan hasil bahwa avoidance motives memiliki hubungan yang signifikan dengan beberapa data demografis responden yaitu usia individu $(r=-0,13, p=$ $0,00 ; p<0,01)$ dan jenis kelamin responden laki-laki $(M=20,92, S D=5,22), t(946)=-1,97, p=0,04 ; p<$ $0,05)$. Ditemukan tidak adanya hubungan yang signifikan antara motif berkorban dan lama berpacaran $(r=-0,90, p=0,90 ; p>0,01)$ pada responden penelitian.

Untuk menjawab rumusan masalah penelitian, peneliti melakukan analisis korelasi antara motif berkorban sebagai variabel bebas dan komitmen sebagai variabel terikat, serta dengan variabel moderator, yaitu neuroticism, terhadap kedua variabel lainnya. Hasilnya akan dijabarkan pada Tabel 4:

Tabel 4. Analisis Utama $(\mathrm{N}=954)$

\begin{tabular}{cccccccc}
\hline & Variabel & M & SD & $\mathbf{1}$ & $\mathbf{2}$ & $\mathbf{3}$ & $\mathbf{4}$ \\
\hline 1 & Approach Motives & 21,60 & 4,25 & 1 & & & \\
2 & Avoidance Motives & 20,23 & 5,25 & $0,62^{* *}$ & 1 & & \\
3 & Komitmen & 36,33 & 4,94 & $0,26^{* *}$ & $0,09^{* *}$ & 1 & \\
4 & Neuroticism & 16,59 & 4,21 & $0,18^{* *}$ & $0,21^{* *}$ & 0,05 & 1 \\
\hline
\end{tabular}

** Korelasi signifikan pada $p<0,01$ ( $t$ wo-tailed $)$

Berdasarkan tabel, antara approach motives $(M=21,60, S D=4,25)$ dan komitmen $(M=36,33, S D=$ 4,94) memiliki korelasi yang positif dan signifikan, $r(953)=0,26, p=0,00 ; p<0,01$, two tails. Dengan demikian, dapat disimpulkan pula bahwa semakin tinggi tingkat komitmen yang dimiliki individu, semakin tinggi kecenderungan individu untuk berkorban dengan approach motives, dan sebaliknya.

Untuk variabel avoidance motives $(M=20,23, S D=5,25)$ dan komitmen $(M=36,33, S D=4,94)$ ditemukan bahwa terdapat korelasi yang positif dan signifikan, $r(953)=0,09, p=0,00 ; p<0,01, t w o$ tails. Dengan kata lain, semakin tinggi tingkat komitmen yang dimiliki individu, semakin tinggi kecenderungan individu untuk berkorban dengan avoidance motives, dan sebaliknya. Dengan demikian, Ho ditolak, dimana terdapat hubungan yang signifikan antara motif berkorban dan komitmen.

Hasil analisis juga menunjukkan adanya hubungan antara masing-masing motif berkorban dengan variabel moderator, neuroticism. Untuk variabel approach motives dan neuroticism ditemukan bahwa terdapat korelasi yang positif dan signifikan, $r(953)=0,18, p=0,00 ; p<0,01, t w o$ tails. Lain halnya dengan variabel avoidance motives dan neuroticism, ditemukan bahwa terdapat korelasi yang positif dan signifikan, $r$ (953) $=0,21, p=0,00 ; p<0,01$, two tails. Dengan kata lain, semakin tinggi tingkat neuroticism yang dimiliki individu, individu akan berkorban bagi pasangannya dengan approach motives maupun avoidance motives. 
Tahapan selanjutnya ialah melakukan teknik analisis moderasi berbasis regresi menggunakan PROCESS SPSS macro. Dilakukan kontrol statistik terhadap variabel lain yang memiliki hubungan signifikan dengan variabel utama penelitian. Berikut hasil analisis

Tabel 5. Hasil Analisis Moderasi pada Variabel Approach Motives

\begin{tabular}{ccccc}
\hline Variabel & $\mathrm{t}$ & $\boldsymbol{p}$ & LLCI & ULCI \\
\hline constant & 2,55 & 0,01 & 2,34 & 18,00 \\
Komitmen & 2,19 & 0,03 & 0,02 & 0,45 \\
Neuroticism & 0,90 & 0,27 & $-0,25$ & 0,67 \\
Interaksi & $-0,19$ & 0,85 & $-0,01$ & 0,01 \\
\hline
\end{tabular}

Analisis moderasi menunjukkan tiga hasil utama. Pertama, ditemukan bahwa terdapat efek komitmen yang signifikan terhadap approach motives $(t=2,55, p=0,01 ; p<0,05)$. Kedua, tidak terdapat efek neuroticism yang signifikan terhadap approach motives $(t=0,90, p=0,27 ; p>0,05)$. Terakhir, tidak terdapat efek interaksi komitmen dan neuroticism yang signifikan terhadap approach motives $(t=-0,19$, $p=0,85 ; p>0,05)$. Dengan demikian, disimpulkan bahwa tidak terdapat hubungan yang signifikan antara approach motives dan komitmen yang dimoderasi oleh neuroticism. Selanjutnya, dilakukan analisis moderasi terhadap avoidance motives.

Tabel 6. Hasil Analisis Moderasi dengan Kontrol Statistik pada Variabel Avoidance Motives

\begin{tabular}{ccccc}
\hline Variabel & $\mathrm{t}$ & $\boldsymbol{p}$ & LLCI & ULCI \\
\hline constant & 3,47 & 0,00 & 7,90 & 28,38 \\
Komitmen & 0,38 & 0,70 & $-0,22$ & 0,32 \\
Neuroticism & 0,51 & 0,61 & $-0,42$ & 0,72 \\
Interaksi & 0,42 & 0,67 & $-0,01$ & 0,02 \\
Usia & $-4,07$ & 0,00 & $-0,39$ & $-0,14$ \\
Jenis Kelamin & 3,39 & 0,00 & 0,59 & 2,24 \\
\hline
\end{tabular}

Terhadap avoidance motives, analisis moderasi yang didapatkan menunjukkan tiga hasil utama. Pertama, tidak terdapat efek komitmen yang signifikan hanya terhadap avoidance motives $(t=3,47, p=$ $0,00 ; p<0,05)$. Kedua, tidak terdapat efek neuroticism yang signifikan terhadap avoidance motives $(t=$ $0,51, p=0,61 ; p>0,05)$. Terakhir, tidak terdapat efek interaksi komitmen dan neuroticism yang signifikan terhadap avoidance motives $(t=0,42, p=0,67 ; p>0,05)$ setelah melakukan kontrol statistik pada data demografis usia dan jenis kelamin responden. Dengan demikian, dapat disimpulkan bahwa tidak terdapat hubungan yang signifikan antara avoidance motives dan komitmen yang dimoderasi oleh neuroticism. Secara keseluruhan, kesimpulan yang dapat diambil ialah hipotesis null kedua pada penelitian gagal ditolak. Dengan kata lain, tidak terdapat hubungan yang signifikan antara komitmen dan motif berkorban yang dimoderasi oleh neuroticism.

\section{Pembahasan}

Hasil penelitian ini menunjukkan bahwa pada dewasa muda yang berpacaran, masing-masing motif berkorban, yakni approach motives maupun avoidance motives, memiliki hubungan dengan komitmen. Hal tersebut sesuai dengan penelitian oleh Van Lange dkk., (1997) yang menemukan bahwa komitmen memiliki hubungan dengan motivasi yang mampu memengaruhi perilaku individu, termasuk kesediaan individu untuk berkorban. Lebih lanjut, ditemukan pula bahwa semakin berkomitmen, individu cenderung semakin lebih mementingkan kesejahteraan pasangan maupun hubungan dari pada dirinya sendiri sehingga individu cenderung mengesampingkan ketertarikannya sendiri. Pada replikasi penelitian yang dilakukan oleh Mattingly dan Clark (2010), ditemukan pula bahwa terdapat hubungan yang signifikan antara komitmen dan berkorban. Menurut Monk, Vennum, Ogolsky, dan Fincham (2014), hal ini dapat terjadi karena semakin meningkat komitmen yang dimiliki individu, ketergantungan akan pasangannya juga akan meningkat sehingga investasi yang akan diberikan dalam 
hubungan tersebut akan meningkat dan salah satu investasi yang dapat dilakukan oleh individu ialah dengan berkorban.

Ditemukan hubungan yang positif dan signifikan antara approach motives dan avoidance motives pada penelitian ini. Hasil penelitian sesuai dengan penelitian Cooper, dkk., (2017) yang menyatakan bahwa dalam berkorban demi pasangannya, bisa saja individu berkorban dengan approach motives dan avoidance motives. Hal tersebut dapat terjadi karena ketika berkorban, individu bergantung dengan kesesuaian situasi dan kondisi yang berlangsung pada saat itu. Dalam masa berpacaran, ada kalanya individu berkorban bagi pasangannya dengan approach motives, tapi dalam lain waktu, bisa saja individu tersebut merelakan keinginan dirinya sendiri demi pasangannya dengan asalan avoidance motives (Cooper, dkk., 2017). Dengan demikian, kedua hal tersebut tidak dapat dipisahkan.

Diteliti lebih lanjut, ditemukan bahwa neuroticism memiliki hubungan yang positif dan signfikan dengan approach motives dan avoidance motives. Akan tetapi, dilihat dari angka korelasinya, terdapat hubungan yang lebih kuat antara neuroticism dengan avoidance motives. Hal ini dapat dijelaskan oleh salah satu karakteristik dari trait neuroticism yaitu memiliki kecenderung akan menghindari semua hal yang dianggap akan menyebabkan masalah bagi dirinya (Ramdhani, 2012). Hasil ini sesuai dengan penelitian Tamir (2005) serta Nikitin dan Freund (2008) yang menyatakan bahwa neuroticism memiliki hubungan dengan active avoidance system secara keseluruhan sehingga individu dengan neuroticism tinggi cenderung akan menghindari ancaman dari segala aspek kehidupannya.

Meskipun neuroticism memiliki hubungan yang signifikan terhadap motif berkorban, dalam penelitian ini ditemukan bahwa neuroticism tidak berfungsi untuk memoderasi hubungan antara komitmen dan motif berkorban pada individu dewasa muda. Hal ini dapat dijelaskan karena terdapat indikasi bahwa hubungan antara komitmen dan motif berkorban begitu kuat sehingga variabel lain kurang mampu memengaruhi hubungan kedua variabel tersebut.

Hubungan yang kuat antara komitmen dan motif berkorban juga didukung oleh beberapa penelitian sebelumnya seperti Wieselquist, Rusbult, Foster, dan Agnew (1999) serta Monk dkk., (2014) yang menyatakan bahwa hubungan antara komitmen dan berkorban dapat terjadi karena merupakan sebuah hubungan timbal balik. Individu yang memiliki komitmen tinggi dapat meningkatkan rasa percaya pada pasangannya dengan cara berkorban, sehingga kualitas hubungan yang dimiliki akan meningkat. Sebagai timbal balik, kualitas hubungan yang kian meningkat juga semakin meningkatkan rasa kepercayaan terhadap pasangannya yang akan mendorong individu untuk berkorban bagi pasangan maupun hubungannya. Dengan demikian, tingkat neuroticism individu tidak cukup kuat untuk memengaruhi hubungan kedua variabel.

Terkait karakteristik demografis, ditemukan bahwa usia dan jenis kelamin memiliki hubungan dengan avoidance motives. Terkait jenis kelamin, ditemukan bahwa responden laki-laki memiliki kecenderungan untuk berkorban dengan avoidance motives. Hal tersebut dapat terjadi karena adanya kemungkinan bahwa perempuan cenderung memandang perilaku berkorban sebagai sebuah tuntutan dan hal yang sudah seharusnya dilakukan dibandingkan laki-laki (Cooper, dkk., 2017). Terkait usia, hasil penelitian menyatakan bahwa semakin muda individu, semakin tinggi kecenderungan individu untuk berkorban dengan avoidance motives. Hal ini terjadi karena sesuai dengan penelitian penelitian Nikitin \& Freund (2008) yang menyatakan bahwa dalam masa transisi memasuki fase dewasa muda, individu cenderung akan menggunakan avoidance motives dalam aspek kehidupan sosialnya, salah satunya ialah saat memiliki hubungan romantis dengan orang lain.

Terkait komitmen, peneliti menemukan hubungan yang positif dan signifikan antara komitmen dan data demografis lama pacaran. Ditemukan bahwa semakin lama durasi individu tersebut berpacaran, semakin tinggi pula komitmen yang dimilikinya. Hal ini sesuai dengan penelitian Rusbult, dkk., (1998) yang menyatakan bahwa individu yang memiliki komitmen tinggi cenderung mampu mempertahankan hubungan yang ia jalani. Hal ini juga diperkuat dengan penelitian yang dilakukan oleh Arriaga dan Agnew, (2001) yang menemukan bahwa individu yang memiliki komitmen tinggi cenderung memiliki intensi yang tinggi untuk bertahan dalam sebuah hubungan. 


\section{Kesimpulan}

Berdasarkan hasil dari pengolahan dan analisis data, terdapat dua kesimpulan untuk menjawab pertanyaan penelitian. Pertama, terdapat hubungan yang signifikan antara komitmen dan motif berkorban pada dewasa muda yang berpacaran. Dengan demikian, individu yang memiliki komitmen tinggi akan cenderung berkorban menggunakan approach motives maupun avoidance motives. Kedua, neuroticism tidak memoderasi hubungan antara komitmen dan motif berkorban pada dewasa muda yang berpacaran. Hasil yang diperoleh ini didapat setelah dilakukan kontrol statistik pada variabel demografis yang memiliki hubungan signifikan dengan motif berkorban, yaitu usia dan jenis kelamin responden. Dengan demikian, ketika individu memiliki komitmen yang tinggi terhadap pasangannya, ia akan tetap berkorban menggunakan approach motives maupun avoidance motives, terlepas dari tingkat neuroticism yang dimilikinya. Trait neuroticism yang dimiliki oleh individu tidak memoderasi hubungan antara komitmen dan motif berkorban.

\section{Daftar Pustaka}

Arriaga, X. B., \& Agnew, C. R. (2001). Being committed: Affective, cognitive, and conative components of relationship commitment. Personality and Social Psychology Bulletin, 279), 1190-1203.

Campbell, S. M. (1980). The couple's journey: Intimacy as path to wholeness. Sydney: Impact Publishers.

Cooper, A. N., Totenhagen, C. J., Curran, M. A., Randall, A. K., \& Smith, N. E. (2017). Daily relationship quality in same-sex couples: Attachment and sacrifice motives. Evolutionary Behavioral Sciences, 11(2), 146.

Feist, J \& Feist, G. J. (2008). Theories of personality (7th Ed.). New York: McGraw-Hill Education

Figueredo, A. J., Sefcek, J. A., \& Jones, D. N. (2006). The ideal romantic partner personality. Personality and Individual Differences, 41(3), 431-441.

Gable, S. L., \& Impett, E. A. (2012). Approach and avoidance motives and close relationships. Social and Personality Psychology Compass, 6(1), 95-108.

Gravetter, F. J., \& Forzano, L. A. B. (2012). Research methods for the behavioral sciences (4th Edition ed.). Belmont: Wadsworth.

Gravetter, F. J., \& Wallnau, L. B. (2009). Statistics for the behavioral sciences. Belmont, CA: Thompson Learning.

Impett, E. A., Gable, S. L., \& Peplau, L. A. (2005). Giving up and giving in: The costs and benefits of daily sacrifice in intimate relationships. Journal of personality and social psychology, 89(3), 327.

Impett, E. A., \& Gordon, A. (2008). For the good of others: Toward a positive psychology of sacrifice. Positive psychology: Exploring the best in people, 2, 79-100.

John, O. P., Naumann, L. P., \& Soto, C. J. (2008). Paradigm shift to the integrative big five trait taxonomy. Handbook of personality: Theory and research, 3(2), 114-158.

Kurdek, L. A. (1997). Relation between neuroticism and dimensions of relationship commitment: Evidence from gay, lesbian, and heterosexual couples. Journal of Family Psychology, 11(1), 109.

Mattingly, B. A. (2008). The effects of sacrifice types and motives on romantic relationship quality. The New School Psychology Bulletin, 5(2), 27-30. 
Mattingly, B. A., \& Clark, E. M. (2010). The role of activity importance and commitment on willingness to sacrifice. North American Journal of Psychology, 12(1).

McCrae, R. R., \& Costa, P. T. (1987). Validation of the five-factor model of personality across instruments and observers. Journal of personality and social psychology, 52(1), 81.

McCrae, R. R., \& Costa, P. T. (2003). Personality in adulthood: A five-factor theory perspective. New York: Guilford Press.

Miller, R. (2014). Intimate relationships. McGraw-Hill Higher Education.

Monk, J. K., Vennum, A. V., Ogolsky, B. G., \& Fincham, F. D. (2014). Commitment and sacrifice in emerging adult romantic relationships. Marriage \& Family Review, 50(5), 416-434.

Nikitin, J., \& Freund, A. M. (2008). The role of social approach and avoidance motives for subjective well-being and the successful transition to adulthood. Applied Psychology, 57(s1), 90-111.

Papalia, D. E., \& Martorell, G. (2014). Experience human development (13th ed). New York: McGraw-Hill Education.

Prakoswa, R. (2018). Milenial Ternyata Rela Putus Pacaran Demi Karir. Retrieved April 10th from https://www.cnbcindonesia.com/lifestyle/20180304105707-33-6125/milenial-ternyata-rela-putuspacaran-demi-karir

Ramdhani, N. (2012). Adaptasi Bahasa dan budaya dari skala kepribadian big five. Jurnal Psikologi, 39(2), 189-205.

Rusbult, C. E. (1980). Commitment and satisfaction in romantic associations: A test of the investment model. Journal of Experimental Social Psychology, 16, 172-186.

Rusbult, C. E. (1983). A longitudinal test of the investment model: The development (and deterioration) of satisfaction and commitment in heterosexual involvements. Journal of Personality and Social Psychology, 45, 101-117.

Rusbult, C. E., Agnew, C., \& Arriaga, X. (2011). The investment model of commitment processes. Department of Psychological Sciences Faculty Publications. Paper 26.

Rusbult, C. E., Martz, J. M., \& Agnew, C. R. (1998). The investment model scale: Measuring commitment level, satisfaction level, quality of alternatives, and investment size. Personal Relationships, 5, 357391.

Tamir, M. (2005). Don't worry, be happy? Neuroticism, trait-consistent affect regulation, and performance. Journal of personality and social psychology, 89(3), 449.

Van Lange, P. A., Rusbult, C. E., Drigotas, S. M., Arriaga, X. B., Witcher, B. S., \& Cox, C. L. (1997). Willingness to sacrifice in close relationships. Journal of personality and social psychology, 72(6), 1373.

Wieselquist, J., Rusbult, C. E., Foster, C. A., \& Agnew, C. R. (1999). Commitment, pro-relationship behavior, and trust in close relationships. Journal of personality and social psychology, 77(5), 942. 
Whitton, S. W., Stanley, S. H., \& Markman, H. J. (2002). Sacrifice in romantic relationships: An exploration of relevant research and theory. In A. Vangelisti \& H. Reis (Eds.), Stability and change in relationships: Advances in personal relationships (pp. 156-181). New York: Cambridge University Press. 